\title{
A global perspective for biodiversity history with ancient environmental DNA
}

\author{
Laura S. Epp
}

Limnological Institute, Environmental Genomics, University of Konstanz, Konstanz, Germany

\section{Correspondence}

Laura S. Epp, Limnological Institute, Environmental Geanomics, University of Konstanz, Konstanz, Germany. Email: laura.epp@uni-konstanz.de

\section{Funding information}

DFG grant 98/3-1 as part of the funding provided by the the 2017-2018 Belmont Forum and BiodivERSA joint call for research proposals, under the BiodivScen ERA-Net COFUND programme

\begin{abstract}
The past centuries have seen tremendous turnovers in species distributions and biodiversity due to anthropogenic impacts on a global scale. The processes are ongoing and mostly not well documented. Long-term records of biotic change can be recovered from sedimentary deposits, but traditional analyses were restricted to organisms that leave behind visible traces and molecular genetic tools were mostly employed on samples that promised good DNA preservation. In this issue of Molecular Ecology, Shaw, Weyrich, Hallegraeff and Cooper (2019) and Gomez Cabrera et al. (2019) present two studies on marine sedimentary records from warm environments, in which they successfully analyze ancient environmental DNA (aeDNA) on a decadal and centennial scale. Notably, the studies were conducted on novel samples with nonoptimal preservation conditions for ancient DNA - historical collections of ship ballast tank sediments from Australia and two coral reef cores spanning up to 750 years (Figure 1) - but yielded a high diversity of taxa. This highlights that aeDNA is a promising tool to globally study biodiversity history on scales of decades to centuries - the timeframe most relevant to human society in the context of both current climate change and direct anthropogenic modifications of the environment.
\end{abstract}

\section{KEYWORDS}

ancient environmental DNA, Anthropocene, biodiversity history, sediments
The potential of aeDNA from sedimentary deposits has been recognized for more than 15 years, but early studies concentrated mostly on high-latitude samples from cold environments with optimal DNA preservation. The first published records presented data from permanently frozen terrestrial deposits in Siberia (Willerslev et al., 2003) and from a lake sediment core from Antarctica (Coolen et al., 2004). An important aspect in early studies was pushing back the temporal limits for the retrieval of aeDNA and many analyses were carried out at the scales of tens or hundreds of thousands of years (Domaizon, Winegardner, Capo, Gauthier, \& Gregory-Eaves, 2017; Parducci et al., 2017). The sites targeted were often remote and unaccessible, and the focus on samples with excellent conditions for DNA preservation (Haile et al., 2009) clouded the view for applying the method in areas in which most humans live: warmer climatic regions.

Furthermore, most early studies using aeDNA concentrated on establishing the presence of the respective organisms in relation to abiotic environmental factors. However, the nature of environmental DNA allows explicit analyses of ecological networks and organism-organism interactions through time (Domaizon et al., 2017). This is the focus of the study of Gomez Cabrera et al. (2019), who investigate correlations in the presence of coral taxa and different algal groups in two reef matrix cores (Figure 1) and find distinct patterns of co-dynamics, which remain hidden in traditional fossil data. Studying such dynamics is particularly pertinent in light of 20 th century ecosystem modifications all over the world, where, for example, neobiota and increased nutrient loads have drastically altered diversity and functionality (Figure 2). As demonstrated by the aeDNA analysis of sediments from ship ballast tanks (Shaw, Weyrich, Hallegraeff, \& Cooper, 2019), historical collections of sediments can furthermore elucidate past global species' distributions and migration routes and provide an efficient tool for monitoring and tracking migrations. 
FIGURE 1 One of the coral reef matrix cores analyzed in Gomez Cabrera et al. (2019): (a) extraction of the core by scuba diving and (b) section of the core showing the sediment matrix and several dated coral fragments (high-precision U-series dating shown as calendar years). Images kindly provided by Dr George Roff
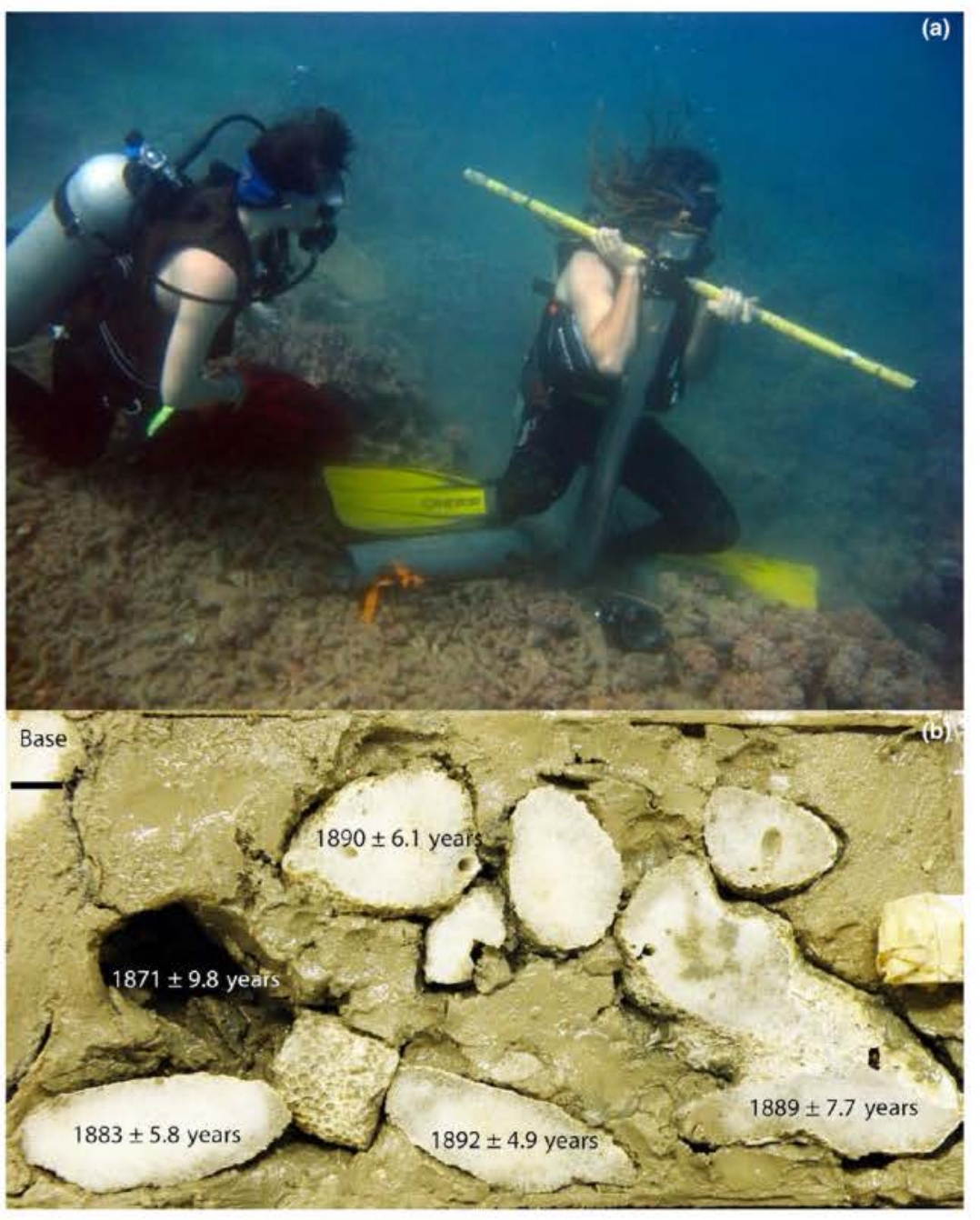

Together, the body of published studies on aeDNA from sediments, and the papers published here (Gomez Cabrera et al., 2019; Shaw et al., 2019), show that the information gained on different temporal scales and from different environments can offer a novel, integrated view on temporal biodiversity change (Balint et al., 2018), and on a global scale. In fact, for many issues that are of immediate relevance for conservation, historic records spanning the last decades or centuries are most important, and these can be obtained from many localities in the world, including tropical environments (Figure 2). It is precisely in the low-latitude areas that anthropogenic modifications of biomes have been most dramatic in the past centuries, in particular the last century (Ellis, Goldewijk, Siebert, Lightman, \& Ramankutty, 2010). To understand ecosystem stability over time prior to the onset of recent anthropogenic disturbances, i.e. prior to the Anthropocene, complementary studies on timescales of multiple thousands of years are needed. These can be carried out in most temperate climates, and can also offer a view on earlier, less intense human impact. Records reaching back tens or hundreds of thousands of years mostly capture ecosystem dynamics that are not influenced by humans. These require samples with particularly good DNA preservation, such as from high-latitude, cold conditions. Information from these different timescales is thus complimentary and can provide a whole new body of empirical data on long-term ecosystem functioning, metacommunity dynamics, as well as ecoevolutionary trajectories.

However, to make full use of available samples, both to understand the patterns of DNA degradation and to properly interpret the data, dedicated studies on the ecology and taphonomy of aeDNA from sedimentary sources are still needed. Surprisingly, and although work is now intensely carried out for environmental DNA in water, similar studies for sediments are very sparse. Most of the existing methodological work on sedimentary DNA has been done on plants, for which an origin from highly local sources has been established (Alsos et al., 2018). This also seems to hold true for aeDNA of coral reefs (Gomez Cabrera et al., 2019). In addition, and as exemplified by the study of Shaw et al. (2019) focussing on taxa involved in harmful algal blooms (HAB), meaningful biological interpretation can best be accomplished with optimal taxonomic assignments of 


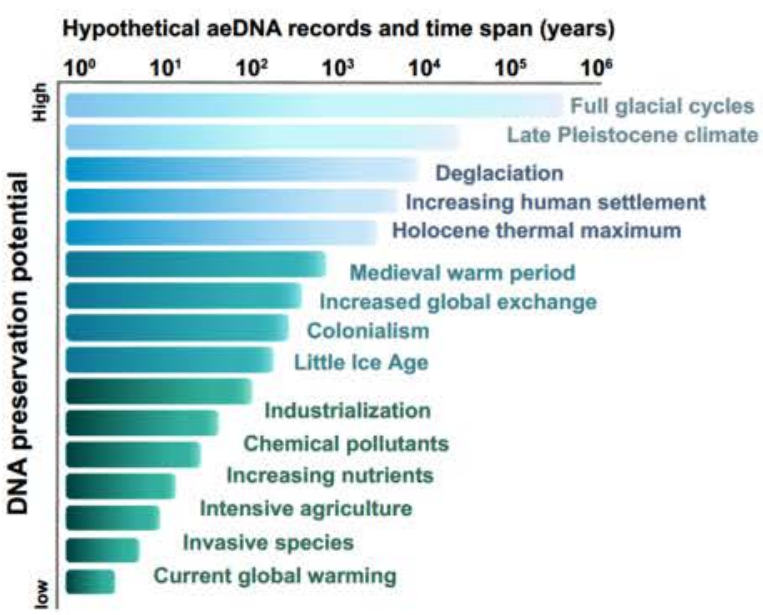

FIGURE 2 Hypothetical records that can be recovered using aeDNA on different timescales, along with a choice of ecologically relevant topics that can be addressed. At sites with low DNA preservation potential, time series on decadal and centennial scales can often be recovered, tracking many current anthropogenic ecological disturbances

target taxa - calling for the further development of high quality sequence reference databases.

In summary, it is now clear that aeDNA can be recovered from a variety of samples and locations globally. While early years of aeDNA research were characterized by the quest to push back temporal limits, we should now work on expanding the geographic limits and provide data that can be of immediate value for conservation and ecosystem management in all regions of the world.

\section{AUTHOR CONTRIBUTION}

L.S.E. conceived and wrote the manuscript.

\section{ORCID}

Laura S. Epp (D) https://orcid.org/0000-0002-2230-9477

\section{REFERENCES}

Alsos, I. G., Lammers, Y., Yoccoz, N. G., Jørgensen, T., Sjögren, P., Gielly, L., \& Edwards, M. E. (2018). Plant DNA metabarcoding lake sediments: How does it represent the contemporary vegetation. PLoS ONE, 13(4), e0195403.

Bálint, M., Pfenninger, M., Grossart, H.-P., Taberlet, P., Vellend, M., Leibold, M. A., ... Bowler, D. (2018). Environmental DNA Time Series in Ecology. Trends in Ecology \& Evolution, 33(12), 945-957. https://doi. org/10.1016/j.tree.2018.09.003

Coolen, M. J. L., Muyzer, G., Rijpstra, W. I. C., Schouten, S., Volkman, J. K., \& Damste, J. S. S. (2004). Combined DNA and lipid analyses of sediments reveal changes in Holocene haptophyte and diatom populations in an Antarctic lake. Earth and Planetary Science Letters, 223(1-2), 225-239. https://doi.org/10.1016/j.epsl.2004.04.014

Domaizon, I., Winegardner, A., Capo, E., Gauthier, J., \& Gregory-Eaves, I. (2017). DNA-based methods in paleolimnology: New opportunities for investigating long-term dynamics of lacustrine biodiversity. Journal of Paleolimnology, 58(1), 1-21. https://doi.org/10.1007/ s10933-017-9958-y

Ellis, E. C., Goldewijk, K. K., Siebert, S., Lightman, D., \& Ramankutty, N. (2010). Anthropogenic transformation of the biomes, 1700 to 2000. Global Ecology and Biogeography, 19(5), 589-606. https://doi. org/10.1111/j.1466-8238.2010.00540.x

Gomez Cabrera, M. D. C., Young, J., Roff, G., Staples, T., Ortiz, J. C., Pandolfi, J., \& Cooper, A. (2019). Broadening the taxonomic scope of coral reef paleoecological studies using ancient DNA. Molecular Ecology, 28, 2636-2652. https://doi.org/10.1111/mec.15038

Haile, J., Froese, D. G., MacPhee, R. D. E., Roberts, R. G., Arnold, L. J., Reyes, A. V., ... Willerslev, E. (2009). Ancient DNA reveals late survival of mammoth and horse in interior Alaska. Proceedings of the National Academy of Sciences of the United States of America, 106(52), 22352-22357. https://doi.org/10.1073/pnas.0912510106

Parducci, L., Bennett, K. D., Ficetola, G. F., Alsos, I. G., Suyama, Y., Wood, J. R., \& Pedersen, M. W. (2017). Ancient plant DNA in lake sediments. New Phytologist, 214(3), 924-942. https://doi.org/10.1111/ nph.14470

Shaw, J., Weyrich, L., Hallegraeff, G., \& Cooper, A. (2019). Retrospective eDNA assessment of harmful algae in historical ship ballast tank and marine port sediments. Molecular Ecology, 28, 2476-2485. https:// doi.org/10.1111/mec.15055

Willerslev, E., Hansen, A. J., Binladen, J., Brand, T. B., Gilbert, M. T. P., Shapiro, B., ... Cooper, A. (2003). Diverse plant and animal genetic records from Holocene and Pleistocene sediments. Science, 300(5620), 791-795. https://doi.org/10.1126/Science.1084114 